\title{
DNA fingerprinting on trial
}

\section{Washington}

A dramatic series of events in a Portland, Maine, courtroom seems certain to lend strength to those calling for stricter standards in the forensic use of DNA testing.

In a preliminary hearing to determine whether evidence from DNA-typing is "sufficiently reliable to be held relevant" as evidence, the prosecution abandoned its case after a series of blunders were revealed under cross-examination.

The prosecution withdrew its DNAprint evidence without the defence having to present a single witness.

The prosecutor, Deputy District Attorney Laurence Gardner, says he has complete faith in the value of genetic fingerprinting but criticized Lifecodes Corporation, the company that prepared the DNA evidence for him, for failing to inform him "of any problem areas that were going to come up".

The trial is the first upset for Lifecodes after the celebrated case in which DNA fingerprint evidence was found unreliable in a 12-week hearing in a Bronx court (see Nature 339, 501; 15 June 1989). The company has successfully presented DNA evidence in some 80 other cases and claims that it is "happy with the results generated" in the Portland case.

Lifecodes spokeswoman Karen Wexler says that the problems in Portland were "in our opinion, more of a function of the prosecutor's willingness to go on with this case, in terms of a commitment of time and perhaps finances to get expert witnesses".

The case involved the sexual molestation of a five-year-old girl. At issue was whether a DNA fingerprint prepared from a semen sample found on a tissue at the scene of the crime matched that prepared from a blood sample taken from the defendant. The 'fingerprint' is the pattern of bands produced when specific fragments of DNA that vary in size according to an individual's genetic makeup are separated out on a gel.

The issue that eventually divided the court was the method Lifecodes used to decide that the patterns on the two gels matched. A straightforward match was not possible because the two fingerprints could not be simply superimposed - all the bands on one gel had run faster than in the other.

Such 'band shifting' is no surprise, as the speed with which DNA migrates across the gel depends on many factors degree of degradation, contaminants and so on. But Lifecodes' way of correcting for the bandshift had not been challenged in court before.

The method is simple. A non-polymorphic marker (a marker for a DNA frag- ment that is the same in all people) is used as a control to estimate the size of the band shift between the two samples. The same correction factor is then applied to other bands on the gel. In this case, a correction calculated by using the non-polymorphic marker DXZ1 generated a match between the two gels. "That indicates", said Gardner, "you could say the evidence and the defendant's blood had a common origin. That was my case".

But then came the bombshell. The defence had in its possession a piece of paper that appeared to show that Lifecodes had also tested a second nonpolymorphic marker, DYZ1. But that probe seemed to generate a completely different correction factor, one that would mean the two samples would not match. Astonishingly, the paper appeared to have been sent to the defence by mistake among other papers they requested.

On the witness stand, Michael Baird of Lifecodes agreed that it should be possible to substitute DYZ1 and DXZ1 "to correct for the migrational difference between the DNA in the evidentiary and the [defendant's] sample". But Baird was then presented with the piece of paper, in his own handwriting, which gave a completely different correction factor using the DYZ1 marker.

"I was devastated. The court was devastated", said Gardner. He had found out that a different non-polymorphic probe gave a different result, "because the defense attorney has a summary fragment sheet in Michael Baird's handwriting that I have never seen. That they never showed to me. That they sent to the defense by mistake." And it appeared from what had happened that Lifecodes had done the most unscientific thing imaginable, which was they had hidden data, not disclosed data that did not agree with their conclusion."

That is not actually true, as Gardner now knows. The reality is that the situation is more complicated than Lifecodes' original explanation suggested. A single non-polymorphic probe can be expected to document only band shifts for DNA fragments of a particular size. Other nonpolymorphic probes may document different shifts in different regions of the gel. There may thus be no contradiction when different results are obtained with different non-polymorphic probes.

Gardner says that, "If they had told me up front that here is a problem ... that you don't really apply the mobility shift across the gel, I could have blunted all that testimony, given the opportunity". But instead, Gardner was stuck with a situation where it appeared that Lifecodes had changed its testimony on the stand, at one moment apparently stating that one non- polymorphic marker alone could be used to correct for band shifting and a little later that different corrections applied in different regions.

Gardner decided not to continue the case. Had he gone on, he would still have faced several more problems - the first being the need for Lifecodes to justify its new method. Although Lifecodes' method is clearly rational - if enough markers are used - experts say they know of no published work that deals with the issue. Lifecodes' reply is that they have data to show their correction method works, although the work has not been published and was not presented to the court.

Naturally enough, this response does not satisfy outside experts who argue that forensic methods need to be generally accepted as valid by the scientific community. But Wexler says that the fact that "it has not been published in a peer review journal does not necessarily mean it is not valid. ... If the prosecutor were to put several expert witnesses on the stand, the FBI perhaps and some other people, all would agree this is a valid way to document the shift."

A further hurdle would still remain. Defence attorney Gene Libby argues that "even if you accept the change in testimony as being correct, they had not done the necessary experiments in this case". He says that they did not have enough non-polymorphic probes to cover the larger DNA fragments and could not have compensated correctly throughout the size range of the gel. Whether his argument is correct is now academic as the Portland case is very unlikely to be reopened.

Defence attorney Gene Libby is clearly pleased by his victory. He had spent a month "studying molecular biology and genetics" before the case and says his example will show other defence lawyers that "this type of evidence can be challenged succesfully and it is not such hard science that it is a waste of time to seek to challenge it".

Alun Anderson

- THE prime source of guidance on the use of genetic fingerprinting now seems likely to be the National Academy of Sciences. The academy announced last week that it had finally won the finances and approval to carry out a 14-month study on DNA Technology in Forensic Science.

Victor McKusick of Johns Hopkins University will chair the 14-person panel. Other members will be named shortly and a first meeting is planned for January.

The project has been planned for some time but financial support has been slow in coming. About $\$ 250,000$ has now been found from the Federal Bureau of Investigation, the National Institute of Justice, the National Science Foundation, the National Institutes of Health and the Sloan Foundation.

NATURE · VOL $342 \cdot$ 21/28 DECEMBER 1989 